\title{
WATER-PRESSURE COUPLING OF SLIDING AND BED DEFORMATION: I. WATER SYSTEM
}

\author{
By R.B. ALLEY* \\ (Geophysical and Polar Research Center, University of Wisconsin-Madison, Madison,
}

Wisconsin 53706-1692, U.S.A.)

ABSTRACr. Analysis of the likely behavior of a water system developed between ice and an unconsolidated glacier bed suggests that, in the absence of channelized sources of melt water, the system will approximate a film of varying thickness. The effective pressure in such a film will be proportional to the basal shear stress but inversely proportional to the fraction of the bed occupied by the film. These hypotheses allow calculation of the sliding and bed-deformation velocities of a glacier from the water supply and basal shear stress, as discussed in the second and third papers in this series.

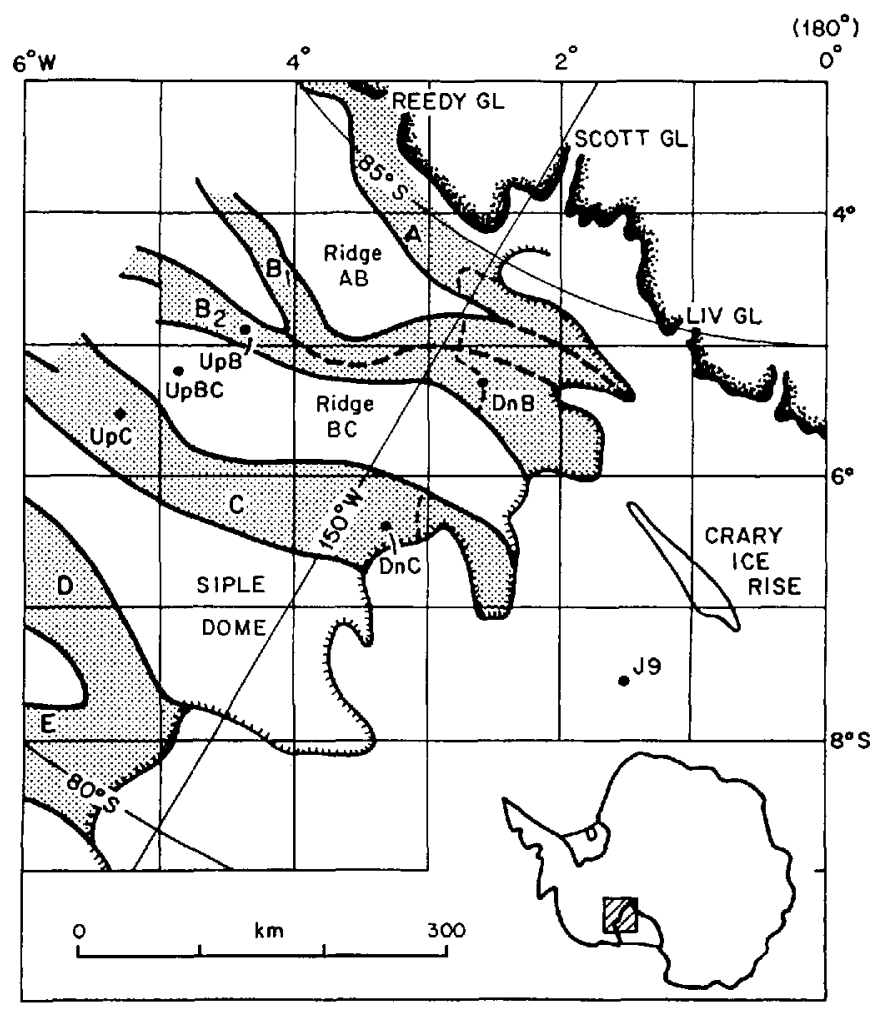

Fig. 1. Location map. Ice Stream $B$ and the other Ross ice streams $(A-E)$ are indentified and shown stippled. The Upstream $B$ camp $(U p B)$ is shown; the flow line in part III runs through UPB and ends near the Downstream $B$ camp (DnB). Modified from Shabtaie and Bentley (1987).

\footnotetext{
* Present address: Earth System Science Center and Department of Geosciences, The Pennsylvania State University, University Park, Pennslyvania 16802, U.S.A.
}

\section{PROLOGUE}

During the 1983-84 Antarctic field season, Blankenship and Bentley (1986) used seismic reflection techniques to discover a meters-thick layer beneath Ice Stream B, West Antarctica, near the Upstream B camp (UpB; Fig. 1). Analysis of data from that field season, and from three subsequent seasons (e.g. Blankenship and others, 1986, 1987, 1989; Rooney and others, 1987a, b, 1988) has shown that this layer is water-saturated and unconsolidated, with low effective pressure (high pore-water pressure) and high porosity. It is continuous, or nearly so, for at least $10 \mathrm{~km}$ by $10 \mathrm{~km}$ near $\mathrm{UpB}$, and seems to occur with similar thickness near the Downstream B camp (DnB; Fig. 1), about $200 \mathrm{~km}$ down-stream. The layer averages $6 \mathrm{~m}$ thick near $\mathrm{UpB}$, with variations from $\leqslant 1 \mathrm{~m}$ to about $12 \mathrm{~m}$. It has a relatively smooth top, but its base is carved into broad flutes $(\approx 10 \mathrm{~m}$ deep by $300-1000 \mathrm{~m}$ across) parallel to ice flow. The layer rests unconformably on a thick sedimentary sequence consisting of poorly consolidated, probably Neogene glaciomarine sediments. Down-stream of DnB beneath the ice plain (a lobate region of ice that would float as part of the Ross Ice Shelf down-stream if it were a few meters thinner, with a surface slope intermediate between that of the ice stream and the ice shelf (Bentley and others, 1987)), the layer appears to be underlain by a packet of sediments tens of meters thick with internal beds dipping about $1 \%$ down-stream.

Following the discovery of this layer, we began a theoretical program to interpret the data collected and to generate hypotheses to guide further field seasons (e.g. Alley and others, 1986, 1987a, b, c, in press). We first considered the question of whether this layer was "lubricating" the ice stream by deforming in a manner similar to that observed by Boulton (1979) beneath Breiđamerkurjökull in Iceland. Three lines of evidence suggested that such subglacial deformation was occurring beneath UpB: the seismically estimated porosity of the layer is consistent with ongoing deformation but is too high for a lodged state, the basal shear stress exceeds the estimated strength of the subglacial layer, and there is insufficient water available at UpB to explain the high ice-stream velocity through any previously published, physically based sliding mechanism without bed deformation. (However, both the shear-strength and the water-balance arguments include the possibility of a rigid bed within their error limits.)

Working from the hypothesis that the bed is deforming, we generated further hypotheses that guided field programs and data analysis. Among the hypotheses that have been verified by geophysical data (insofar as the data have been reduced) are the continuity of the layer, its relative constancy of thickness, and the existence of ice plains underlain by thick accumulations of sediment with the observed internal structures.

Previously, we have concentrated on developing hypotheses testable by surface geophysical techniques on Ice Stream B. It now seems likely that a drilling program during the 1988-89 and 1989-90 field seasons by Dr B. 
Kamb and co-workers of the California Institute of Technology and collaborating institutions will reach the bed of Ice Stream B directly, and that other drilling programs may produce larger access holes further in the future.

In this series of papers, we attempt to use geophysical data and glaciological reasoning to develop hypotheses for conditions at a drill site on Ice Stream B. In part I, I analyze the likely water-drainage system and water-pressure distribution at the bed, and show how these are linked to bed deformation. In part II (Alley, 1989), I calculate possible velocity-depth profiles in the bed, and show how a measured profile can be used to constrain the flow law for till deformation. In part III (Alley and others, 1989), we use available data and inferences to focus the results of parts I and II on Ice Stream B. The major hypotheses arising from these analyses are that most of the ice-stream velocity arises from basal deformation, that most of the subglacial water flows in a distributed system approximating a thin film at the ice-till interface, that effective pressure decreases down-glacier and is quite small, that the form of the ice stream provides information about the flow law for till, and that this flow law can be determined with better accuracy if effective pressure, deformational velocity, and grain-size are measured against depth in a deforming subglacial till at one or more sites.

\section{TERMINOLOGY}

For these papers, we consider the glacier bed to be all materials beneath glacier ice. The bed is ice-free for the wet-based glaciers considered here; the definition of the bed would be more problematic for a debris-carrying, coldbased glacier advancing over permafrost, for example. The thickness of the bed is not well defined and does not matter in general, although the depth to which significant glaciogenic deformation occurs is of concern.

The glacier bed includes both the bulk of subglacial materials and their upper surface. The upper surface is characterized by its roughness, the fractional area occupied by water, and other areal properties. The bulk of the subglacial materials is characterized by density, viscosity, grain-size distribution, and other bulk properties. If any ambiguity seems likely, we specify explicitly whether a given property of the bed refers to the bulk or to the upper surface. A glacier bed may be "hard" (rigid and nondeforming under glaciogenic stresses even for water pressure equal to overburden pressure), although subject to erosion, or "soft" (likely to deform under glaciogenic stresses if water pressure is sufficiently close to overburden pressure).

Basal motion of a glacier may occur through sliding, bed deformation, or ploughing. Sliding is motion between the base of a glacier and the top of the bed across a discrete, generally water-lubricated shear surface. Bed deformation refers to motion within the bulk of the bed, and may occur between closely spaced clast-clast contacts (pervasive deformation) or along discrete shear surfaces more widely separated than the average clast diameter. Ploughing is a transitional state between sliding and bed deformation, in which the ice slides over some clasts that are fixed in the rigid bed, whereas the basal velocity is partitioned between sliding over other clasts and motion ("ploughing") of those clasts through the bed, which deforms locally to allow this motion (Brown and others, 1987).

\section{SYMBOLS USED AND VALUES OF CONSTANTS}

Units and first paper and equation or figure in which symbol appears are indicated.

Power of shear stress in till-flow law $(I, 1)$.

Geometric factor in ploughing index (II,5).

Arbitrary area of bed; $\mathrm{m}^{2}$ (I).

Power of effective stress in till-flow law $(I, 1)$

Accumulation rate of ice; $\mathrm{m} \mathrm{s}^{-1}$ (III).

Creep-closure softness for ice; $\mathrm{Pa}^{-3} \mathrm{~s}^{-1}(\mathrm{I}, 13)$.

Constant equal to $\tau_{\mathrm{b}} / N$ at onset of specified basal behaviour $(I, 16)$.

Cohesion; Pa $(1,3)$

Water-film thickness; $\mathrm{m}(\mathrm{I}, 24)$. $\begin{array}{ll}d_{c} & \text { Controlling obstacle height; } m(\mathrm{I}, 27 \mathrm{a}) . \\ f & \text { Fraction of bed occupied by interconnected }\end{array}$ water $(I, 17)$.

$g \quad$ Acceleration of gravity; $9.8 \mathrm{~m} \mathrm{~s}^{-2}(\mathrm{I}, 11)$.

Ice thickness; m (III, fig. 1).

Ploughing index for clasts in $j$ th size class $(I 1,5)$.

Counter for number of clast-size classes

(I,Al).

$J_{0} \quad$ Sediment-flux constant; $\mathrm{s}^{2} \mathrm{~m}^{-2}(\mathrm{I}, 5)$.

Sediment flux in a channel; $\mathrm{m}^{3} \mathrm{~s}^{-1}(\mathrm{I}, 5)$.

Hydraulic conductivity; $\mathrm{m} \mathrm{s}^{-1}(\mathrm{I}, \mathrm{Il})$.

Sliding softness coefficient $\approx K_{\mathrm{s}} d_{\mathrm{c}} / 10 ; \mathrm{m} \mathrm{s}^{-1}$ $\mathrm{Pa}^{-2}$ (1,27a).

$K_{\mathrm{b}} \quad$ Till-softness coefficient; $\mathrm{s}^{-1} \mathrm{~Pa}^{b-a}(\mathrm{I}, 1)$.

$K_{\mathrm{s}} \quad$ Sliding-sof tness coefficient; $\mathrm{s}^{-1} \mathrm{~Pa}^{-2}(\mathrm{I}, 27 \mathrm{~b})$.

$K_{\mathrm{b} \max } \quad$ Maximum value of $K_{\mathrm{b}}$ from $x=25-300 \mathrm{~km}$

for fixed $a, b$ but all $\gamma ; \mathrm{s}^{-1} \mathrm{~Pa} b-a$ (III,

fig. 4).

$K_{\text {bmax }} \quad$ Maximum value of $K_{\mathrm{b}}$ from $x=100-300 \mathrm{~km}$ for fixed $a, b, \gamma ; \mathrm{s}^{-1} \mathrm{~Pa}^{b-a}$ (III, fig. 3).

$K_{\text {bmin }}$ '

$L$

Minimum value of $K_{\mathrm{b}}$ from $x=100-300 \mathrm{~km}$

for fixed $a, b, \gamma ; \mathrm{s}^{-\mathrm{P}} \mathrm{Pa}^{b-a}$ (III, fig. 3).

Latent heat of fusion of ice; $3.1 \times 10^{8} \mathrm{~J} \mathrm{~m}^{-3}$ (I,13).

Basal melt rate; $\mathrm{m} \mathrm{s}^{-1}(\mathrm{I}, 12)$.

Inverse of Manning roughness coefficient; $\mathrm{Pa}^{-1 / 2} \mathrm{~m}^{5 / 6} \mathrm{~s}^{-1}(\mathrm{I}, 6)$.

Effective pressure, $P_{i}-P_{w} ; P a(I, 1)$.

$N$
$N^{*}$

Effective pressure in Humphrey (1987) model;

$\mathrm{Pa}(\mathrm{I}, 23)$.

$N_{\mathrm{c}} \quad$ Effective pressure at which driving stress for till-channel closure equals yield strength; $\mathrm{Pa}$ $(I, 15)$.

$N_{\mathrm{H}} \quad$ Effective pressure for hydrostatic pore-fluid pressure gradient, $\mathrm{Pa}$ (II,17).

$N_{\ell} \quad$ Effective pressure for laminar channel flow, Pa $(1,13)$.

$N_{1 j} \quad$ Local effective stress on a clast in $j$ th size class, $P_{\mathrm{b} j}-P_{\mathrm{w}} ; \mathrm{Pa}(\mathrm{II}, 5)$.

$N_{\text {L }} \quad$ Effective pressure for lithostatic pore-fluid pressure gradient, $\mathrm{Pa}(\mathrm{II}, 18)$.

$N_{\max }$

$N_{0}$

$N_{\mathrm{t}}$

$P_{\mathrm{b}}$
$P_{\mathrm{b} j}$

$P_{\mathrm{g}}$

$P_{\mathrm{i}}$

$q$

$q_{i}$

$Q$

$Q_{x}$

$\dot{r}$

${ }_{s}{ }_{j}$

$s \quad$ Fraction of base of ice in contact with clasts,

Maximum value of effective pressure for interconnected water film; $\mathrm{Pa}(I, 16)$.

Effective pressure at ice-till interface, $\mathrm{Pa}$ (II, 16).

Effective pressure for turbulent channel flow, $\mathrm{Pa}(\mathrm{I}, 13)$.

Vertical normal stress on a clast: $\mathrm{Pa}(\mathrm{I}, 18)$.

Vertical normal stress on a clast in $j$ th size class; Pa (I,Al).

Magnitude of pressure gradient driving water flow, $\mathrm{Pa} \mathrm{m}^{-1}(\mathrm{I}, 6)$.

Average normal ice stress on bed; $\mathrm{Pa}(I, 2)$.

Water pressure in interconnected regime; $\mathrm{Pa}$ (I,2).

Water flux per unit width; $\mathrm{m}^{2} \mathrm{~s}^{-1}(\mathrm{I}, 25)$.

Water flux per unit width at head of ice stream, $\mathrm{m}^{2} \mathrm{~s}^{-1}$ (III).

Water flux in channel; $\mathrm{m}^{3} \mathrm{~s}^{-1}(\mathrm{I}, 8)$.

$\partial Q / \partial x ; \mathrm{m}^{2} \mathrm{~s}^{-1}(\mathrm{I}, 9)$.

Channel radius; $m(1,4)$.

Time-rate of change of channel radius; $\mathrm{m} \mathrm{s}^{-1}$ $(\mathbf{I}, 4)$.

Clast radius in $j$ th class; $m(I I, 2)$.

$=1-f(I, 18)$.

Value of $s$ for clasts in $j$ th size class, $\sum_{j} s_{j}=s(\mathbf{I}, \mathbf{A l})$.

Velocity of till deformation; $\mathrm{m} \mathrm{s}^{-1}$ (II, fig. 1).

Depth average of $u ; \mathrm{m} \mathrm{s}^{-1}$ (II,29).

Ice velocity; $\mathrm{m} \mathrm{s}^{-1}$ (II, fig. 1 ).

Value of $u_{i}$ at $\mathrm{UpB} ; \mathrm{m} \mathrm{s}^{-1}$ (III,11).

Velocity at top of deforming till; $\mathrm{m} \mathrm{s}^{-1}($ II, 13).

Sliding velocity between ice and top of till; $\mathrm{m} \mathrm{s}^{-1}(\mathrm{I}, 27 \mathrm{a})$.

$u_{\mathrm{s}}$

$\begin{array}{ll}u_{\mathrm{SB}} & \text { Value of } u_{\mathrm{s}} \text { at } \mathrm{UpB}, \mathrm{m} \mathrm{s}^{-1} \text { (III,11). } \\ U_{\mathrm{m}} & \text { Mean velocity of water flow in a channel; }\end{array}$ $\mathrm{m} \mathrm{s}^{-1}(\mathrm{I}, 5)$.

$U_{\mathrm{me}} \quad$ Mean velocity of laminar flow in a channel; 


\begin{tabular}{|c|c|}
\hline$U_{\mathrm{mt}}$ & $\begin{array}{l}\mathrm{ms}^{-1}(\mathrm{I}, 6) \text {. } \\
\text { Mean velocity of turbulent flow in a channel; } \\
\mathrm{m} \mathrm{s}^{-1}(\mathrm{I}, 6) \text {. }\end{array}$ \\
\hline$v_{m}$ & Basal melt rate; $\mathrm{m} / \mathrm{s}(\mathrm{III}, 3)$ \\
\hline$V_{j}^{m}$ & $\begin{array}{l}\text { Volume fraction in till occupied by clasts in } \\
j \text { th size class (II, } 1) \text {. }\end{array}$ \\
\hline$V_{\mathbf{p}}$ & $\begin{array}{l}\text { Volume fraction in till occupied by pores } \\
(I, 1) \text {. }\end{array}$ \\
\hline$x$ & Horizontal coordinate; $m(I, 7)$ \\
\hline$z$ & Vertical coordinate; m (II, fig. 1 ). \\
\hline$z_{0}$ & $\begin{array}{l}\text { Depth at which effective pressure in till is } \\
\text { twice the effective pressure at the ice-till } \\
\text { interface; } m(11,25) \text {. }\end{array}$ \\
\hline$z_{1}$ & $\begin{array}{l}\text { Thickness of pervasively deforming layer; } m \\
(I I, 13) \text {. }\end{array}$ \\
\hline$z_{2}$ & $\begin{array}{l}\text { Depth at which basal shear stress equals } \\
\text { strength of pervasively deforming till; m } \\
\text { (II,20). }\end{array}$ \\
\hline$z_{3}$ & $\begin{array}{l}\text { Depth at which strain-rate falls to minimum } \\
\text { required to maintain dilation; } m \text { (II,30). }\end{array}$ \\
\hline$\alpha_{b}$ & Slope of ice-bed interface $(I, 26)$ \\
\hline$\alpha_{s}$ & Slope of ice-air interface $(I, 26)$ \\
\hline$\beta^{\circ}$ & $\begin{array}{l}\text { Ratio of vertical deviatoric stress to shear } \\
\text { stress on a clast }(I, 17) \text {. }\end{array}$ \\
\hline$\beta^{\prime}$ & $\begin{array}{l}\text { Geometric constant relating } N^{*} \text { and } \tau_{b} \text { in bed } \\
\text { without low-pressure ice-rock contact }(I, 23) \text {. }\end{array}$ \\
\hline$\gamma$ & $\begin{array}{l}\text { Fraction of ice velocity at UpB from sliding, } \\
=u_{\mathrm{sB}} / u_{\mathrm{iB}}(\mathrm{III}, 11) \text {. }\end{array}$ \\
\hline$\Delta$ & $\begin{array}{l}\text { Relative variation in } K_{\mathrm{b}} \text { for given } a, b, \gamma \text { on } \\
x=100-300 \mathrm{~km},=\left(K_{\mathrm{b} \max }{ }^{\prime}-K_{\mathrm{b} \min }{ }^{\prime}\right) /\left(K_{\mathrm{b} \max }\right. \\
\left.+K_{\text {bmin }}{ }^{\prime}\right) \text { (III, fig. } 3 \text { ). }\end{array}$ \\
\hline
\end{tabular}

Difference between bulk density and porefluid density; $\mathrm{kg} \mathrm{m}^{-3}$ (II, 16).

Strain-rate in till; $\mathrm{s}^{-1}(\mathbf{I}, 1)$.

$\dot{\varepsilon}$

$\zeta_{j}$

$\mu$

$\mu_{\mathrm{b}}$

$\xi_{\mathrm{c}}$

$\xi_{\mathrm{el}} \mathrm{e}$

$\xi_{\text {et }}$

$\xi_{\mathrm{t}}$

$\rho_{\mathrm{b}}$

$\rho_{\mathrm{i}}$

$\rho_{W}$
$\tau^{*}$

$\tau_{j}^{*}$

$\tau_{\mathrm{b}}$

$\tau_{\mathrm{e}}$

$\tau_{\mathrm{e} j}$

$\tau_{j}$

$\phi$

$x$

$\psi$

$\omega$

Fraction of total shear force supported on

clasts of $j$ th size class, $=\tau_{j} / \tau_{\mathrm{b}}$ (II,9).

Viscosity of water; $1.8 \times 10^{-3} \mathrm{~Pa} \mathrm{~s}(\mathrm{I}, 6)$.

Bingham viscosity of till; Pa S (II,13).

Creep closure rate of a channel; $s^{-1}(I, 4)$.

Erosion rate of a till channel; $s^{-1}(I, 7)$.

Value of $\xi_{\mathrm{e}}$ for laminar flow; $\mathrm{s}^{-1}(\mathrm{I}, 9)$.

Value of $\xi_{\mathrm{e}}$ for turbulent flow; $\mathrm{s}^{-1}(\mathrm{I}, 9)$

Closure rate of $\mathbf{R}$ channel in laminar flow; $\mathrm{s}^{-1}$ (I, 14).

Net closure rate for a channel; $s^{-1}(I, 14)$.

Closure rate of $R$ channel in turbulent flow; $s^{-1}(I, 14)$

Bulk density of till; $\mathrm{kg} \mathrm{m}^{-3}$ (II, 17).

Density of ice; $\mathrm{kg} \mathrm{m}^{-3}(\mathrm{I}, 26)$.

Density of water; $\mathrm{kg} \mathrm{m}^{-3}(\mathrm{I}, 10)$.

Stress causing channel closure; Pa $(I, I)$.

Till yield stress; $\mathrm{Pa}(1,1)$.

Yield stress for ploughing of clasts in $j$ th size class; Pa (II, 15).

Basal shear stress; Pa $(I, 16)$.

Effective basal shear stress in Bingham model; $\mathrm{Pa}($ II, 13).

Value of $\tau_{\mathrm{e}}$ for clasts in $j$ th size class; $\mathrm{Pa}$ (II, 15).

Shear force on bumps in $j$ th size class and in unit area of bed; $\sum_{j} \tau_{j}=\tau_{b} ; \mathrm{Pa}(1,20)$.

Angle of internal friction of till; $\operatorname{deg}(\mathrm{I}, 3)$.

Dimensionless depth for water-pressure doubling, $\equiv z_{0} / z_{1}$ (II, table I).

Dimensionless depth, $\equiv z / z_{1}$ (II, table I)

Fraction of potential deforming thickness

from yield stress actually deforming, $\equiv z_{1} / z_{2}$ (II, table I).

\section{INTRODUCTION}

Basal motion of glaciers is perhaps the most interesting, important, and difficult problem in dynamic glaciology. The modern, physical treatment of ice sliding over a rigid bed now has occupied a central position in glaciology for over 30 years (Weertman, 1957), and there is no sign that interest in the problem has waned (e.g. Fowler, 1987; Kamb, 1987). Many of the problems associated with the physics of sliding over rigid beds have been solved, although considerable uncertainty still exists about the geometry of such beds.

Glacial geologists and glaciologists have long recognized that bed deformation can occur beneath glaciers (e.g. MacClintock and Dreimanis, 1964). Direct observational evidence of bed deformation providing a large fraction of the basal velocity was obtained first beneath Blue Glacier, Washington, U.S.A. (Engelhardt and others, 1978) and Breiđamerkurjökull, Iceland (Boulton, 1979). There now is direct or indirect evidence for bed deformation contributing to basal motion beneath a number of glaciers, including (but not limited to) South Cascade Glacier, Washington, U.S.A. (Hodge, 1979), Nordenskiöldbreen, Spitsbergen (Boulton and Paul, 1976), Variegated Glacier, Alaska, U.S.A. (Harrison and others, 1985), Columbia Glacier, Alaska, U.S.A. (Fahnestock and Humphrey, 1988; Meier, 1989), Trapridge Glacier, Yukon Territory, Canada (Clarke and others, 1984), and Ice Stream B, West Antarctica (Alley and others, 1986).

The relative frequency of bedrock beds, non-deforming till beds, and deforming till beds is unknown, although some theoretical considerations have been advanced with regard to till versus bedrock beds by Haeberli (1986). Despite the signal papers by Clarke (1987) and Boulton and Hindmarsh (1987), it can be argued that neither the physics nor the geometry of deforming beds are well known. In addition, the interactions of deforming beds and sliding are poorly understood.

One general result of studies of basal conditions is that the geometry and pressure of the basal water system are critically important. Fast basal motion, whether by sliding or bed deformation, is possible only if water pressure is relatively close to overburden pressure (e.g. Boulton and Hindmarsh, 1987; Clarke, 1987; Fowler, 1987; Kamb, 1987), and water pressure depends on water supply and drainage path.

In this paper, I consider the likely drainage paths and water pressures on deforming beds. I attempt generality for a variety of glacier settings, but concentrate on conditions likely to apply to Ice Stream B. I attempt to include the essential physics and an indication of likely geometry, but the discussion is partly heuristic to maintain simplicity. Nonetheless, I believe that the available evidence leads directly to the hypothesis that, in the absence of input of surficial melt water, the drainage system at the interface of ice and a soft-sediment bed will be distributed (no channels or linked cavities), and high pressure (within about 1 bar of overburden or less).

\section{DRAINAGE PATH}

\section{Porous flow}

Water may be supplied to a glacier bed by melting at the bed (distributed source), downward transport of englacial or supraglacial melt or precipitation (distributed or localized source), stream transport from unglaciated regions (localized source), or porous flow from subglacial aquifers (distributed source). Under ordinary conditions, the water head is higher beneath most ice sheets and some glaciers than in their surroundings, so porous flow and stream flow will be away from the ice mass. Distributed englacial transport of water generated englacially or supraglacially occurs through very small veins (Nye and Frank, 1973), is restricted to temperate glaciers, and generally is small compared to basal melt and channelized englacial transport on such glaciers (summarized in Paterson (1981, p. 36-38)). Channelized englacial transport of water occurs on temperate glaciers, and can occur and might reach the bed on cold glaciers with abundant surface melt (e.g. Echelmeyer and Harrison, 1986). However, only basal melt supplies water to glacier beds beneath dry-firn and percolation zones, which occupy the majority of land ice on Earth. I will concentrate on this case.

Ignoring exceptional events during which the bed supplies water to an englacial or supraglacial water system (e.g. Meier, 1989), water is removed from the glacier bed by porous flow downward into subglacial aquifers and outward beyond the margin, or by flow along the ice-bed interface to the ice edge. The porous flow system has been considered by a number of authors (e.g. Boulton and others, 
1974; Boulton and Jones, 1979; Clarke and others, 1984; Boulton and Hindmarsh, 1987; Clarke, 1987; Lingle and Brown, 1987).

The porous flow system has a limited ability to transport water. If this transport capacity is large compared to the water supply, then basal water pressures will be low, ice will maintain intimate contact with its bed, and basal sliding and bed deformation will be slow or zero. Such a situation is favored by thick, high-permeability subglacial aquifers, slow basal melt rates, and short flow paths (small glaciers). The physics of water flow under these conditions is well known; the major complications are the effect of any basal deformation that may occur on the permeability and on advection of water during such deformation (Boulton and others, 1974; Alley and others, 1987b), and the major difficulty is in obtaining data on the thickness, extent, and permeability of subglacial aquifers.

Most of the analyses cited above suggest that subglacial aquifers are likely to prove inefficient for large, wet-based ice sheets even in the absence of surficial melt water, especially if basal ice velocities and thus basal melting are rapid. As an example, drainage of the melt water from a $1000 \mathrm{~km}$ long ice sheet arising from the viscous dissipation of an average sliding velocity of $25 \mathrm{~m} / \mathrm{a}$ under an average shear stress of $10^{5} \mathrm{~Pa}$ ( 1 bar) with the head gradient for water flow driven by an ice-air surface slope of 0.01 would require a continuous aquifer of clean, unconsolidated sand about $250 \mathrm{~m}$ thick (hydraulic conductivity $10^{-4} \mathrm{~m} / \mathrm{s}$; Freeze and Cherry, 1979, p. 29). The aquifer would need to be significantly thicker, or have higher permeability, to lower the hydraulic head and head gradient and thus to be efficient compared to the water supply.

If the basal drainage system is unable to evacuate all of the water supplied to it, then water must accumulate at the ice-bed interface and increase the water pressure until a drainage system is established there. Unless a frozen region of bed down-stream dams flow, a drainage system at the ice-bed interface has an unlimited capacity; in the highflow limit, the ice will float on the water whereas the water will "float" on the underlying, denser sediment. One might expect that a slow increase in a distributed water source above the capacity of subglacial aquifers would give rise to a distributed flow system (i.e. a thin water film) at the ice-bed interface. With increasing water supply, instabilities might develop in that film (Walder, 1982) and cause channelized flow unless blocked by some other process.

Analogy can be drawn to subaerial drainage of precipitation on hillslopes, as described in any good text on that subject (e.g. Bloom, 1978, p. 198-200). If rainfall is sufficiently slow, and the surficial materials are sufficiently thick and permeable, all of the rainfall will infiltrate into the soil and no free water will exist at the upper surface. With increasing rainfall, the water supply will saturate the aquifer and cause free water to accumulate at the surface. This water then will flow down-hill in a sheet or film a few millimeters thick and broken by grass stems, large clasts, roots, and other irregularities. Only when the flow is sufficiently thick and fast does it become concentrated into rills, and this concentration can be avoided in most instances if the flow is slowed and baffled sufficiently, as by good agricultural practices.

For modeling purposes (of glacier beds or hillslopes), an aquifer that is efficient compared to the water supply lacks surficial drainage, which need not be modeled. This is the situation treated by Boulton and others (1974), for example. With increasing water supply, there is some intermediate condition in which flow volumes through aquifers and through a surficial system are similar, and both must be modeled. Finally, there is a situation in which the flow is dominated by the upper-surface system, and the aquifers can be ignored to good approximation. The limiting case of this is the impermeable bed used in many glacialhydrological models; however, this situation can exist over a quite permeable bed if enough water is supplied. This is the situation I will concentrate on here.

\section{Geometry of interconnected basal regime}

Water drainage at the glacier bed must occur through an interconnected water system (Lliboutry, 1987a), which may include channels incised upward into the ice ( $R$ channels; Röthlisberger, 1972) or downward into the bed (N channels; Nye, 1973), linked cavities (Walder, 1986; Kamb, 1987), or a water film of variable thickness (Weertman, 1972). For free water to exist stably at the glacier bed without being displaced by creeping ice, it is necessary that the local melting rate equals the local creep-closure rate. Creep closure increases with effective pressure (the difference between the overburden pressure and the water pressure), and local melting from viscous dissipation increases with channelization of flow. Thus, in a steady system, effective pressure increases as flow becomes increasingly localized from films to linked cavities to channels (Röthlisberger, 1972; Weertman, 1972; Walder, 1986; Kamb, 1987), although this relation is largely independent of geometric details.

Whether drainage at the ice-bed interface occurs in channels, cavities, films, or some combination, and the size and spacing of those drainage paths, are important and difficult questions. It seems likely that all possibilities occur in natural systems, so the difficulty becomes one of determining where and when any given system exists.

The relative stability of $R$ channels and water films illustrates the complexity of this question. Walder (1982) showed that the enhanced viscous dissipation in the thicker regions of a perturbed water film will cause the perturbations to grow, but that heat flow within the film and ice creep tend to retard perturbation growth, and incipient channels may be destroyed by sliding over bedrock obstacles. Walder (1982) concluded that a water film thicker than a few millimeters probably would be unstable over a rigid bed, especially under the influence of large pressure gradients driving flow. This instability must be self-limiting at some level on an impermeable bed, however, because the stress distribution around an $R$ channel prevents it from collecting water at the ice-bed interface (Weertman and Birchfield, 1983).

A water film on an impermeable bed fed by basal melt thus may exhibit transverse thickness variations or may cycle between a fairly uniform film and a channelized configuration, but cannot collapse into a stable channel system because such a system cannot collect the basal water needed to sustain itself (Weertman and Birchfield, 1983). Notice, however, that a channel supplied by surface melt water has no need to collect basal water and can exist stably (Weertman and Birchfield, 1983). A similar analysis for $N$ channels indicates that they are more stable than $R$ channels, but probably also require channelized surficial melt water to maintain themselves for long periods of time (Weertman, 1972).

This conclusion is strengthened if the glacier bed is soft. Under appropriate conditions, sediment as well as ice will creep into low-pressure channels, and sediment creep must be balanced by erosion just as ice creep is balanced by melting to maintain a steady configuration (Boulton and Hindmarsh, 1987). Such sediment flow into low-pressure, air-filled tunnels has been observed directly beneath Breiđamerkurjökull (Boulton, 1976). In the next section, I extend the analysis of Boulton and Hindmarsh (1987) to show that sediment erosion in channels fed by basal water is an inefficient process, and that sediment creep will close channels or cavities rapidly in the absence of surficial melt water.

\section{Channel instability on a deforming bed}

A proper constitutive relation for a deforming sediment is likely to be complicated (e.g. Iverson, 1985). For relatively simple stress states, however, a reasonable relation is (Boulton and Hindmarsh, 1987)

$$
\begin{gathered}
\dot{\varepsilon}=K_{\mathrm{b}} \frac{\left(\tau-\tau^{*}\right)^{a}}{N^{b}}, \tau>\tau^{*} \\
\dot{\varepsilon}=0, \tau \leqslant \tau^{*}
\end{gathered}
$$

where $\dot{\varepsilon}$ is the strain-rate, $\tau$ is the shear stress, $\tau^{*}$ is the sediment strength, and $a, b$, and $K_{\mathrm{b}}$ are constants. The effective stress, $N$, is the difference between the overburden normal stress and the water pressure, $P_{w}$. At the base of the ice, where the overburden normal stress on the bed is the ice normal stress, $P_{i}$, this gives 


$$
N=P_{\mathrm{i}}-P_{\mathrm{w}}
$$

The yield strength, $\tau^{*}$, usually is written as

$$
\tau^{*}=N \tan \phi+C
$$

where $\tan \phi$ is the internal friction and $C$ is the cohesion of the sediment. Equation (1) includes as special cases linearviscous behavior $\left(a=1, b=0, T^{*}=0\right)$ and Bingham behavior $\left(a=1, b=0, \tau^{*}\right.$ from Equation (3)); in these cases, $1 / K_{\mathrm{b}}$ is the viscosity.

Boulton and Hindmarsh (1987) measured $N$ and $\dot{\varepsilon}$ and calculated $\tau$ at several locations beneath Breiđamerkurjökull in Iceland. They fitted their observations using Equation (1), both with $\tau^{*}=0$ and $\tau^{*}$ given by Equation (3), and used standard soils engineering tests to measure the material parameters in Equation (3). They found that Equation (1) described the data well and yielded $b>a$ in both cases.

Following Boulton and Hindmarsh (1987; based on Nye, 1953), creep closure of a tunnel in till occurs in response to $N$, which they take to be the difference between the water pressure in a tunnel and the basal ice pressure. (If the stress state around the tunnel is not hydrostatic, then closure rates will vary with direction. I follow Boulton and Hindmarsh (1987) in ignoring this complication, and I take $N$ to be the difference between the overburden stress and the water pressure in the tunnel.) Assuming continuum behavior given by Equation (1), with $\tau=N$ for the driving stress, a tunnel of radius $r$ creeps closed at a rate $\dot{r}$ given by

$$
\begin{aligned}
& \xi_{\mathrm{c}}=K_{\mathrm{b}} \frac{\left(N-\tau^{*}\right)^{a}}{N^{b} a^{a}}, N>\tau^{*} \\
& \xi_{\mathrm{c}}=0, N \leqslant \tau^{*} \\
& \xi_{\mathrm{c}} \equiv \frac{\dot{r}}{r}
\end{aligned}
$$

where the subscript $c$ refers to creep closure. Boulton and Hindmarsh (1987) set $\tau^{*}$ to zero in their analysis; notice from Equation (3) that $\tau^{*}$ contains a dependence on $N$ here.

Equation (4) applies to a channel of circular crosssection with $N$ independent of position. In real tills, the roof would cave in for a large channel, and $N$ might vary from top to bottom of a large channel. The physically realistic case is of an $N$ channel carved into till at the icebed interface, with or without a corresponding $R$ channel above. I will call this special case of an $\mathbf{N}$ channel in unconsolidated sediment a till channel. The equations above should describe such a till channel reasonably well, and I will assume that they do, although they ignore the effect of coupling across the ice-till interface on the creep closure of the ice. (Similarly, I will ignore such coupling in modeling $R$ channels over a deforming bed, below.)

For a till channel to exist in steady state, the creep closure, $\xi_{c}$, must be balanced by erosion of equal magnitude, $\xi_{\mathrm{e}}$. Clean, channelized surficial melt water supplied to the bed would cause rapid erosion until the water became "saturated" with sediment (that is, until the water carried its full capacity of sediment). Basally derived water is always in contact with sediment and in steady state will carry its sediment capacity. Erosion along some stretch of channel will then be limited to the increased capacity caused by collection of water along that channel.

Sediment flux in a channel, $J_{S}$, can be approximated by (Allen, 1985, p. 60)

$$
J_{\mathrm{s}}=J_{0} \pi r^{2} U_{\mathrm{m}}^{3}
$$

where $U_{\mathrm{m}}$ is the mean flow velocity and $J_{0}$ is a constant. (In some formulations $J_{\mathrm{s}}$ drops to zero below a threshold value of $U_{\mathrm{m}}$; I ignore this complication here.) The velocity, $U_{\mathrm{m}}$, is given by (e.g. Weertman, 1972)

$$
U_{\mathrm{m} \ell}=\frac{P_{\mathrm{g}} r^{2}}{8 \mu}
$$

$$
U_{\mathrm{mt}}=M P_{\mathrm{g}}{ }^{1 / 2} r^{2 / 3}
$$

where subscripts $\ell$ and $t$ refer to laminar and turbulent flow, respectively, $P_{g}$ is the magnitude of the volumetric fluid-potential gradient along flow (the water-pressure gradient in a horizontal channel), $\mu$ is the water viscosity, and $M$ is the inverse of the Manning roughness coefficient. The erosion rate, $\xi_{\mathrm{e}}=\dot{r} / r$, is

$$
\xi_{\mathrm{e}}=\frac{1}{2 \pi r^{2}} \frac{\partial J_{\mathrm{s}}}{\partial x}
$$

where $x$ is distance measured along the channel.

To obtain a more convenient expression for $\xi_{\mathrm{e}}$ in terms of the water influx to the channel, I first assume that $J_{0}, \mu, M$, and $P_{\mathrm{g}}$ are independent of $x$. I then substitute for $U_{\mathrm{m}}$ in Equation (5) from Equation (6), differentiate with respect to $x$, and substitute for the $x$ derivative of $J_{\mathrm{S}}$ in Equation (7) to obtain an expression for $\xi_{\mathrm{c}}$ in terms of constants, $r$, and the $x$ derivative of $r$. Next, notice that $r$ is related to the water flux, $Q$, by

$$
Q=\pi r^{2} U_{\mathrm{m}}
$$

Substituting for $U_{\mathrm{m}}$ in Equation (8) from Equation (6), differentiating with respect to $x$, solving for the $x$ derivative of $r$, and substituting for that derivative in the modified form of Equation (7) then yields

$$
\begin{aligned}
& \xi_{\mathrm{e} \ell}=\frac{J_{0} P_{\mathrm{g}}^{2} r^{2} Q_{x}}{64 \pi \mu^{2}} \\
& \xi_{\mathrm{et}}=\frac{3 J_{0} M^{2} P_{\mathrm{g}} Q_{x}}{4 \pi r^{2 / 3}}
\end{aligned}
$$

where $Q_{x}$ is the $x$ derivative of $Q$, and thus the water influx to the channel. Steady state occurs when the creep closure equals the erosion rate, which is found by equating Equations (4) and (9).

The laminar-turbulent transition occurs within a narrow range of Reynolds numbers centered on (Weertman, 1972)

$$
\frac{2 r \rho_{\mathrm{w}} U_{\mathrm{m}}}{\mu}=2300 .
$$

Here $\rho_{W}$ is the density of water, with turbulent flow at higher velocities and laminar flow at lower velocities.

The water influx, $Q_{\mathrm{X}}$, depends on the rate of water supply at the bed and on the area from which a channel can collect water (Shoemaker, 1986). I have chosen two estimates for calculations here. The first is the maximum possible collection by a tunnel in a porous half-space, assuming that the water table is not drawn down by the tunnel from a height $N / \rho_{w} g$ above the center of the tunnel (Goodman and others, 1965; Freeze and Cherry, 1979, p. 490),

$$
Q_{x}=\frac{2 \pi K N}{\rho_{\mathrm{w}} g \ln \left[\frac{2 N}{\rho_{\mathrm{w}} g r}\right]}
$$

where $K$ is the hydraulic conductivity of the till and $g$ is the magnitude of the gravitational acceleration. This can give very high water inflows at high $N$. For example, equating Equations (4) and (9) in turbulent flow for $r=1 \mathrm{~m}$, using the constants given at the beginning of the paper and in Table I and $Q_{x}$ from Equation (11), gives $N=10^{7} \mathrm{~Pa}$ and $Q_{x}$ equivalent to collection of all water from a basal melt rate of $10 \mathrm{~mm} / \mathrm{a}$ over a width of $2400 \mathrm{~km}$. may be

A more reasonable approximation for water collection

$$
Q_{x}=10^{4} r \dot{m}
$$

where $\dot{m}$ is the basal melt rate. This assumes that a channel collects all water generated in a band $10^{t}$ times as wide as 


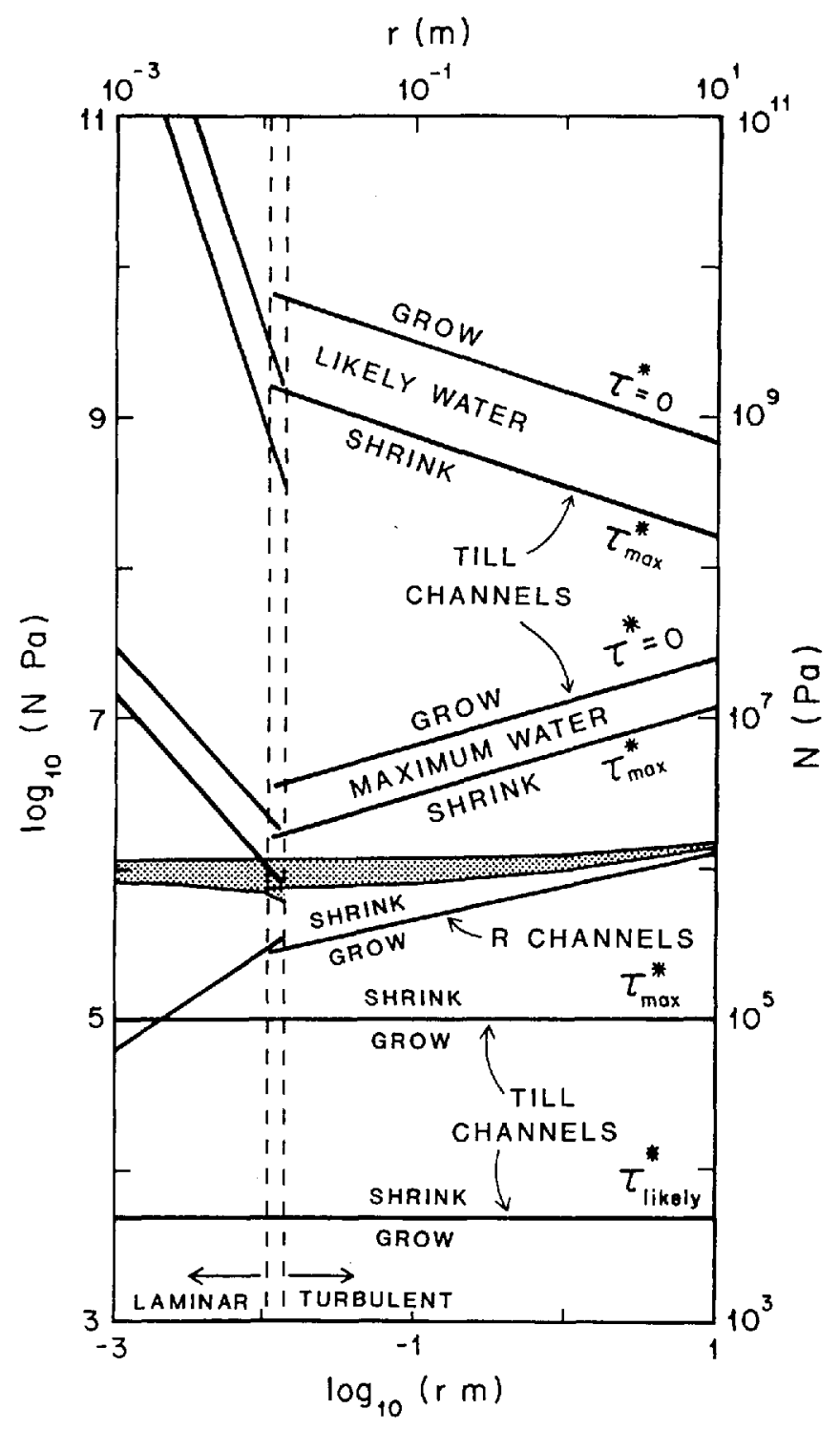

Fig. 2. Effective pressure $(N)$ plotted against channel radius $(r)$ for Röthlisberger $(R)$ and till channels. Till channels exhibit stability at high $N$ and at low N. Four high-N till-channel stability curves are shown, corresponding to iikely (Equation (12)) and maximum (Equation (11)) water collection for both $T^{*}=0$ (zero till yield strength) and $\tau^{*}$ the maximum till yield strength from Sladen and Wrigley (1983; $C=25 \mathrm{kPa}$, tan $\phi=0.75)$. A till channel plotting above its high- $N$ stability line grows; one plotting below shrinks. Low-N till-channel stability curves are plotted for $\tau^{*}{ }_{\max }$ and for a likely value of yield strength ( $\tau^{*}$ ikey; $\quad C=4 \mathrm{kPa}$, tan $\left.\phi=0.2\right) ; \tau^{*}=0$ plots off-scale at low $N$. The stippled band includes those values of $(N, r)$ for which the shrinkage rates of till and $R$ channels are equal, for the till-stability cases shown. The laminar-turbulent transition occurs between the vertical dashed lines. its radius. Under this assumption, a $1 \mathrm{~m}$ radius channel would drain a $10 \mathrm{~km}$ wide glacier.

The constant $10^{4}$ in Equation (12) is a crude estimate, but it may be a good estimate for large channels and an overestimate for small channels. Modern mountain glaciers hundreds of meters to kilometers across typically are drained by one or a few large streams on the order of $1 \mathrm{~m}$ in radius (e.g. Humphrey and others, 1986), although surficial melt water figures prominently in the drainage system. Walder and Hallet (1979) found that subglacial channels draining surficial melt from a small cirque glacier were typically $0.1-0.3 \mathrm{~m}$ across and were spaced $\leqslant 5 \mathrm{~m}$ apart, although no preferred spacing was observed. Subaerial water flows on unconsolidated sediments develop their smallest perturbations (rills) with a spacing on the order of $10 \mathrm{r}$ (e.g. Emmett, 1978). In the absence of better data (which clearly would be beneficial), I will use Equation (12) as a more restrictive estimate than the upper limit given in Equation (11). Notice, however, that the conclusions reached below are valid for Equation (11) although strengthened for Equation (12).

Estimates of $N$ for steady-state till channels are plotted in Figure 2, using the constants in Table $I$ and calculating $Q_{\mathrm{X}}$ according to Equations (11) (maximum water) and (12) (likely water); remember that "likely" water probably overestimates $Q_{\mathrm{X}}$ and underestimates $N$ at small $r$. The melt rate and pressure gradient are taken to match Ice Stream $B$, with flow driven by the ice-air surface slope. The constants $a, b$, and $K_{\mathrm{b}}$ in Table $\mathrm{I}$ were calculated as best-fit values for Ice Stream B (see part III); $a$ and $b$ fall within likely error limits determined by Boulton and Hindmarsh (1987). The till hydraulic conductivity is from Boulton and others (1974), the inverse of the Manning roughness coefficient is from Weertman (1972), and $J_{0}$ was estimated using data on sediment transport in a stream draining Variegated Glacier in its pre-surge state (Humphrey and others, 1986). Sensitivity to errors in constants is discussed below.

Curves in Figure 2 are shown for $\tau^{*}=0$ and for the upper limit on $\tau^{*}$ in a basal till, from the data summarized by Sladen and Wrigley $(1983 ; C=25 \mathrm{kPa}, \tan \phi=0.75)$. Likely intermediate values of $\tau^{*}$ would plot between these limiting curves. The $\tau^{*}=0$ curve at low $N$ plots off-scale, so an intermediate value $(C=4 \mathrm{kPa}, \tan \phi=0.2)$ is plotted there as $\tau^{*}{ }_{\text {likely }}$.

For comparison, Figure 2 also contains the steady-state values for $R$ channels in laminar and turbulent flow, calculated using the same constants (including inverse roughness, $M$ ) following Weertman (1972)

$$
\begin{gathered}
N_{\ell}=\left[\frac{P_{\mathrm{g}}^{2} r^{2}}{16 B \mu L}\right]^{1 / 3} \\
N_{\mathrm{t}}=\left[\frac{M P_{\mathrm{g}}^{3 / 2} r^{2 / 3}}{2 L B}\right]^{1 / 3}
\end{gathered}
$$

where $B$ is related to the creep hardness of ice, $H$ is the heat of fusion of ice, and ice is assumed to obey power-law creep with exponent 3 (Weertman, 1972). The difference between the creep-closure rate and the melt rate of an R channel, ( $\xi)_{\text {net }}$, is (Weertman, 1972)

TABLE I. VALUES OF CONSTANTS USED TO CALCULATE CURVES IN FIGURES 2 AND 3

$\begin{array}{ll}a & 1 \\ b & 2 \\ B & 1.8 \times 10^{-25} \mathrm{~Pa}^{-3} \mathrm{~s}^{-1} \\ C & 0,4,25 \mathrm{kPa}^{-2} \\ g & 9.8 \mathrm{~m} \mathrm{~s}^{-2} \\ J_{0} & 1.5 \times 10^{-5} \mathrm{~s}^{2} \mathrm{~m}^{-2} \\ K & 10^{-6} \mathrm{~m} \mathrm{~s}^{-1} \\ K_{\mathrm{b}} & 0.33 \mathrm{~Pa} \mathrm{~s}^{-1}\end{array}$

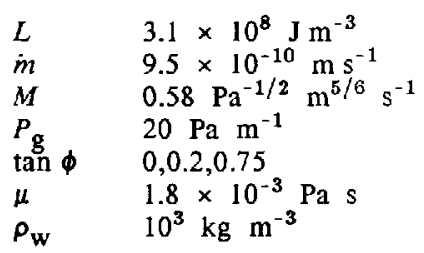




$$
\begin{gathered}
\left(\xi_{\ell}\right)_{\text {net }}=B N^{3}-\frac{P_{\mathrm{g}}^{2} r^{2}}{16 \mu L} \\
\left(\xi_{\mathrm{t}}\right)_{\text {net }}=B N^{3}-\frac{M P_{\mathrm{g}}^{3 / 2} r^{2 / 3}}{2 L} .
\end{gathered}
$$

Figure 2 also shows the range of values of $N$ in which $(\xi)_{\text {net }}$ is the same for $R$ channels and for till channels. $(\xi)_{\text {net }}$ for till channels is the difference between Equations (4) and (9).

Contours of $(\xi)_{\text {net }}$ are shown in Figure 3 for $R$ channels and for till channels; closure is positive and growth is negative. For the till, I have assumed $C=4 \mathrm{kPa}$ (Boulton and Hindmarsh, 1987) and $\tan \phi=0.2$ (Alley and others, 1987b).

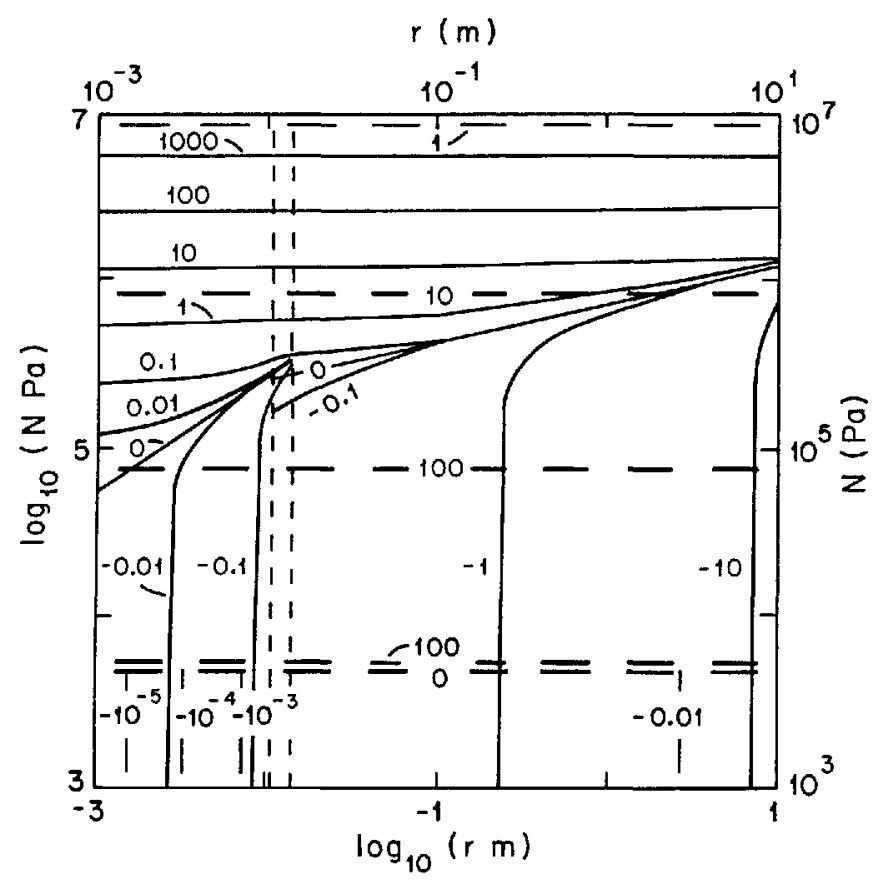

Fig. 3. Net shrinkage rates ( $\dot{r} / r$ in $\left.a^{-1}\right)$ of $R$ channels (solid lines) and till channels (long-dashed lines) as a function of channel radius $(r)$ and effective pressure $(N)$. Negative numbers show channel growth. Calculations for till channels assume the yield strength $\tau^{*}{ }_{\text {likely }}(C=4 \mathrm{kPa}$, tan $\phi=0.2$ ) and likely water collection (Equation (12)). At low $N$, contours of till-channel closure are vertical. Also for till channels, the 1 and 10 contours would fall between the 0 and 100 contours near the bottom of the figure, but are omitted because of space limitations. The vertical short-dashed lines show the laminar-turbulent transition zone.

Examination of Figures 2 and 3 reveals several interesting results. Till channels exhibit two steady configurations: one at low $N$, where the driving stress is low, and one at high $N$, where the till viscosity is high. The high $N$ values with likely water collection are impossible for real glaciers, however, because they require higher $N$ than would occur in a channel at atmospheric pressure beneath the thickest ice on Earth. The low $N$ values occur at $N$ close to but above $N_{\mathrm{c}}$, the critical value at which the driving stress for creep closure equals the till yield strength, given by

$$
N_{\mathrm{c}}=\frac{C}{1-\tan \phi} .
$$

For Figure $3, N_{\mathrm{c}}=5 \mathrm{kPa}$. The low $N$ equilibrium occurs close to $N_{\mathrm{c}}$ because erosion by basal water is quite slow, and is balanced by slow creep closure and thus small driving stress $\left(N-T^{*}\right)$.
Figure 3 shows that steady-state $R$ channels occur in a zone of rapid creep closure of till channels. An $R$ channel at the ice-till interface thus would be closed rapidly by till creep. This is true for all except the strongest tills; the limiting till strength from Sladen and Wrigley (1983) $(C=$ $25 \mathrm{kPa}, \tan \phi=0.75$ ) would allow co-existence of steady $R$ channels and till channels with $2 \mathrm{~mm}$ radii, but till would creep into larger steady $R$ channels. The largest steady $R$ channel that can exist over a till bed has $N \approx N_{\mathrm{c}}$ for that till bed, and a rigid bed relative to channelized drainage is one for which $N_{\text {c }}$ exceeds the value of $N$ in the largest $\mathbf{R}$ channel that the glacier could develop over a perfectly rigid bed.

Figure 3 also shows that steady, low $N$ till channels exist in a region of $\mathbf{R}$-channel growth. This essentially is the instability explored by Walder (1982) for rigid beds; at low $N$, perturbations in a distributed water system tend to grow.

The discussion here has assumed continuum mechanics, and thus that the grain-size of tills is small compared to the channels under consideration. This probably is true for most tills if channels are $>0\left(10^{-2} \mathrm{~m}\right.$ ) (the symbol $O(x)$ means "of the order of magnitude of $\left.x^{\prime \prime}\right)$. However, channels of $\leqslant 0\left(10^{-3} \mathrm{~m}\right)$ may be similar in size to common clasts and may be protected from creep closure by bridging of clasts (a rigid clast cannot creep into a channel smaller than itself). Millimeter-scale $\mathbf{R}$ channels thus might approach their steady value of $N$ more closely than is possible for larger $R$ channels on a till bed. However, the concept of a channel becomes somewhat unclear at this scale.

Figures 2 and 3 were calculated assuming specific values of till properties, water-pressure gradient, water generation, and other factors; however, the general results obtained are relatively robust. Use of the Boulton and Hindmarsh (1987) constants rather than the Ice Stream B constants in Equation (4) would have raised the already high $N$ values for steady, high- $N$ till channels, but otherwise would not have changed the results significantly. If $a>b$ in Equation (4), then the high- $N$ stability of till channels would disappear, but behavior at low $N$ again would be similar. If $K_{\mathrm{b}}$ were decreased by an order of magnitude, all creep-closure rates of till channels in Figure 3 would be reduced by an order of magnitude; however, this would leave all steady $R$ channels smaller than about $r=1 \mathrm{~m}$ in a zone of rapid creep closure by till. Figure 3 was calculated using those values of $\tan \phi$ and $C$ I believe appropriate for dilated, deforming till, and thus for a glacier on a pervasively deforming bed. Using values for a strong, lodged till bed could raise the zero line for creep-closure rate of till channels as high as $10^{5} \mathrm{~Pa}\left(T^{*}\right.$ max in Figure 2). However, initiation of creep deformation (all regions above the zero line) would dilate the till, so the spacing between the zero and $100 /$ year lines would not change significantly, and steady $\mathrm{R}$ channels with $r>10 \mathrm{~mm}$ would fall in a region of rapid creep closure of till channels. An order-of-magnitude error in $J_{0}, K_{\mathrm{b}}$, or $K$ could move the stability field for high- $N$ till channels with maximum water collection and maximum till yield strength quite close to the $R$-channel stability field for $r \geqslant 10 \mathrm{~mm}$. However, errors of 3-4 orders of magnitude would be required to allow co-existence of stable $R$ channels and till channels with likely water; the likely water case also is independent of $K$.

I thus hypothesize that a water system between ice and a soft-sediment bed without sources of channelized surficial melt water will be distributed, approximating a film but with local thickenings up to millimeters in radius. The effective pressure will be above $N_{c}$ but not above the equilibrium value for $R$ channels millimeters in radius, and thus between 0 and perhaps $400 \mathrm{kPa}$. It is difficult to constrain this estimate more closely, but considering the rapid creep-closure rates of tills with $N$ near but above $N_{\mathrm{c}}$, and likely values of $N_{\mathrm{c}}, N \approx 0\left(10^{4} \mathrm{~Pa}\right)$ may be a reasonable estimate. The system probably will evolve rapidly, with local thickenings growing but then being closed by till creep. In the next section, I work from this hypothesis and attempt to model the ice/water/bed system assuming that drainage occurs through a film. (The important case of channelized surficial melt water supplied to a soft glacier bed is beyond the scope of the present papers.) 


\section{WATER PRESSURE IN A FILM}

From the discussion above, viscous dissipation in a distributed water system is slow, and water can accumulate in a region only if the water pressure equals or exceeds the local ice pressure. The basal shear stress from ice overlying a wet bed causes sliding and variation in the ice normal stress on the bed about its mean value, $P_{\mathrm{i}}$, during upward and downward motion of the ice over roughness elements (Nye, 1969; Kamb, 1970). If water pressure becomes sufficiently high, the thickened regions of water will become sufficiently widespread to communicate along the ice-bed interface and to maintain a relatively uniform water pressure, $P_{w}$, over the communicating regions (the interconnected regime; Lliboutry, 1987a).

For a water film, Weertman (1972) estimated that interconnection requires that the effective pressure, $N=P_{\mathrm{i}}-P_{\mathrm{w}}$, be less than or equal to the root-meansquare fluctuation in local ice normal stress on the bed necessary to allow sliding without cavitation. From Kamb (1970; p. 723), the maximum value of $N$ for interconnection in a film then is

$$
N_{\max } \leqslant \tau_{\mathrm{b}} / c_{1}
$$

where $\tau_{\mathrm{b}}$ is the basal shear stress and the constant, $c_{1}$, depends on bed roughness and varies from about $1 / 2$ to 1/9. For $\tau_{\mathrm{b}}=20 \mathrm{kPa}$ (typical of Ice Stream B), an intermediate roughness value gives $N \leqslant 100 \mathrm{kPa}$ for an interconnected water film.

As long as there are regions of the bed in which the local ice pressure is less than the average ice pressure, an increase in water pressure can cause the water film to expand. This will increase the fraction of the bed, $f$, occupied by the water film. The water-film fraction $f$ thus can be expected to vary inversely with $N$ in some fashion. In addition, fluctuations in local ice pressure increase with $\tau_{\mathrm{b}}$ (Nye, 1969; Kamb, 1970), so for given $f$ one would expect $N$ to increase with $\tau_{\mathrm{b}}$. The simplest relation that incorporates these ideas is

$$
N=\frac{B \tau_{\mathrm{b}}}{f}
$$

where $B$ is a geometric factor. This relation has acceptable limiting behavior (as $f$ increases toward 1 , both $\tau_{b}$ and $N$ approach 0 ; as $f$ decreases toward $0, N$ ceases to be defined because interconnection of the water film breaks down), and I now argue that this may be a good first approximation of the actual relation.

First consider unit area of a horizontal glacier bed with average vertical ice stress $P_{\mathfrak{i}}$, with a single bump occupying fractional area $s$ and sustaining vertical stress $P_{b}$, and with water occupying fractional area $f=1-s$ at pressure $P_{\mathrm{w}}$. Vertical force balance on unit area then requires

$$
P_{\mathrm{b}} s+P_{\mathrm{w}}(1-s)=P_{\mathrm{i}}
$$

whence

$$
\left(P_{\mathrm{b}}-P_{\mathrm{w}}\right) s=P_{\mathrm{i}}-P_{\mathrm{w}}
$$

The water supports no shear stress, so the bump supports the horizontal shear stress $\tau_{\mathrm{b}}$ on its area $s$ for a local shear stress of $\tau_{\mathrm{b}} / s$. This local shear stress causes an excess vertical force on the bump, which causes ice flow over the bump and which can be expressed as

$$
P_{\mathrm{b}}=P_{\mathrm{i}}+\frac{B \tau_{\mathrm{b}}}{s}
$$

where $B$ is the ratio of the excess vertical stress to the shear stress on the area $s$ of the bump. From Equations (19) and (20)

$$
B t_{\mathrm{b}}=\left(P_{\mathrm{i}}-\mathrm{P}_{\mathrm{w}}\right)(1-s),
$$

or, remembering $N=P_{\mathrm{i}}-P_{\mathrm{w}}$ and $f=1-s$,

$$
N=\frac{B T_{\mathrm{b}}}{f} .
$$

Equation (22) is valid for a bed with a range of bump sizes, as shown in the Appendix. This equation holds provided $\tau_{b}$ does not exceed the maximum value that can be supported by the bed (Iken, 1981). The $\tau_{\mathrm{b}}-N$ relation of Equation (22) has been known for some time (see Lliboutry, $1987 \mathrm{a}, \mathrm{b}$, and his earlier papers); the ratio $f / \beta$ in Equation (22) is equivalent to the bed separation index of Bindschadler (1983). In deriving Equation (22), I have assumed that $N$ is not lowered by melting from viscous dissipation and that the water system is interconnected. The equation thus should apply to regions between channels fed by moulins as well as to glacier beds without moulins, if all quantities are defined over a relatively homogeneous region without channels.

When all low ice-pressure regions of the bed are occupied by water, further increases in water pressure do not cause further ice-bed separation. Humphrey (1987) showed that the effective pressure then becomes constant at $N^{*}$ given by

$$
N^{*}=\beta^{\prime} \tau_{b}
$$

where $\beta^{\prime}$ can be related directly to the bed geometry in simple cases. Humphrey (1987) also showed that this defines the limiting basal shear stress that a bed can support, as discussed by Iken (1981)

Whether a glacier bed falls in a regime described by Equation (22) or (23) depends strongly on the bed geometry. A bed of smooth rock with a few large steps may exhibit a relatively narrow range of local ice pressures less than the average ice pressure, and all of these low-pressure regions may accumulate water before an interconnected drainage system develops. Such a linked cavity system then will be decribed by Equation (23), as modeled by Humphrey (1987).

In contrast, a till bed containing a wide range of grain-sizes will have a similarly wide range of local ice pressures. Equation (22) then will be a better model, and redistribution of local ice pressures during increasing cavitation may allow this equation to apply until quite large fractions of the bed are occupied by water.

It then seems likely that Equation (23) will apply to many glaciers with relatively homogeneous beds, including granitic bedrock and very clast-poor tills. Equation (22) is likely to apply to glaciers with inhomogeneous beds, including most tills and other poorly sorted sediments and poorly sorted sedimentary rocks. The case of a till or other unconsolidated sediment very poor in clasts larger than $O(1 \mathrm{~mm})$ might be especially interesting. If a till does not form roughness elements larger than its clasts (e.g. drumlins or similar forms), and clasts of $>0(1 \mathrm{~mm})$ are rare or absent, then a water film of $>0(1 \mathrm{~mm})$ thick will essentially float the glacier, causing very low $N$ and $\tau_{\mathrm{b}}$ and very high velocities through sliding or bed deformation.

The derivations in this section clearly oversimplify the true glacier bed, and are partially heuristic as a consequence. Nonetheless, I hypothesize that Equation (22) provides a reasonable estimate of subglacial conditions on most till beds and other rough surfaces, at least if used to interpolate between measured values or to extrapolate near measured values. Thus, if $N, \tau_{b}$, and $f$ are measured at a site, Equation (22) can be used to estimate $\beta$ and to estimate $N$ for relatively small changes in $\tau_{\mathrm{b}}$ or $f$. We adopt this approach in part III.

\section{WATER DRAINAGE IN A FILM}

Equation (22) is a powerful tool for modeling basal behavior of a glacier with water-film drainage. This is because Equation (22) provides a direct link between the water system and the velocities from sliding and bed deformation.

The fractional area covered by interconnected water, $f$, must increase with the average thickness of the water film, 
$d$, in some manner that depends on bed geometry. Thus

$$
f=f(d)
$$

where the functional relation can be calculated from the bed geometry (see part II).

Water flow in a film of thickness $d$ has been described by (Weertman, 1972; Weertman and Birchfield, 1982)

$$
d=\left(\frac{12 \mu q}{P_{\mathrm{g}}}\right)^{1 / 3}
$$

where $q$ is the water flux in $\mathrm{m}^{3} / \mathrm{s}$ per meter width. If channels or linked cavities are present, then $P_{g}$ is measured from the film to these conduits. In the absence of conduits,

$$
P_{\mathrm{g}}=\rho_{\mathrm{j}} g \alpha_{\mathrm{S}}+\left(\rho_{\mathrm{w}}-\rho_{\mathrm{i}}\right) g \alpha_{\mathrm{b}}
$$

where $\rho_{i}$ and $\rho_{w}$ are the densities of ice and water, respectively, and $\alpha_{s}$ and $\alpha_{b}$ are the surface and bed slopes, respectively. (I do not calculate $P_{\mathrm{g}}$ for drainage controlled by conduits here because conduit drainage is unlikely under Ice Stream B.)

Finally, from Weertman sliding theory (Weertman, 1957, 1964, 1969; Weertman and Birchfield, 1982), we can estimate the sliding velocity, $u_{\mathrm{s}}$, which is approximated by

$$
u_{\mathrm{s}}=K_{1} \tau_{\mathrm{b}}^{2}\left[1+10 \frac{d}{d_{\mathrm{c}}}\right], d<0\left(d_{\mathrm{c}}\right)
$$

or

$$
u_{\mathrm{s}} \approx K_{\mathrm{s}} \tau_{\mathrm{b}}^{2} d, \quad d \geqslant 0\left(d_{\mathrm{c}}\right)
$$

where $d_{\mathrm{c}}$ is the controlling obstacle size. (In Weertman sliding theory (Weertman, 1964), the resistance offered by obstacles to ice sliding exhibits a maximum value for some obstacle size; obstacles of that size are called controlling obstacles, and their size is $d_{\mathrm{c}}$. Typically, $d_{\mathrm{c}}=0(1-10 \mathrm{~mm})$.) $K_{1}$ and $K_{\mathrm{s}}=10 K_{1} / d_{\mathrm{c}}$ are constants that depend on bed roughness and other factors. The value of $K_{\mathrm{s}}$ can be estimated from Weertman theory (Weertman, 1964) if the bed geometry is known, or calculated from approximation $(27 \mathrm{~b})$ if all other terms are measured.

The water supply, bed geometry, and basal shear stress thus allow calculation of the effective pressure and sliding velocity for a glacier with a distributed water system. In addition, the effective pressure, basal shear stress, and bed properties allow calculation of the basal velocity from bed deformation, using Equation (1). It thus becomes possible to use the nature and geometry of the bed and ice plus the water supply to calculate the total basal velocity of a glacier.

\section{HYPOTHESES}

Analysis of the likely behavior of a water system developed between ice and an unconsolidated glacier bed leads to the following testable hypotheses:

In the absence of channelized sources of melt water, the water system will be distributed, approximating a film of varying thickness.

Effective pressure, $N$, in such a distributed water system over a soft bed will fall between $N_{c}=C /(1-\tan \phi)$, where $C$ is cohesion and $\tan \phi$ is internal friction of the bed, and the steady value for $R$ channels millimeters in radius. $N=0(10 \mathrm{kPa})$ seems most likely.

Effective pressure can be approximated as $N=B \tau_{\mathrm{b}} / f$, where $B$ is a geometric factor, $\tau_{b}$ is the basal shear stress, and $f$ is the fractional area of the bed occupied by the water film.
The basal velocity from sliding and bed deformation can be estimated from these hypotheses, the water supply, and the properties and geometry of the bed and ice.

This last hypothesis is explored more fully in part II.

\section{ACKNOWLEDGEMENTS}

I thank C.R. Bentley, D.D. Blankenship, T.J. Hughes, and S.T. Rooney for helpful comments on the manuscript, and I am indebted to J.S. Walder for numerous suggestions and criticisms, not all of which are answered satisfactorily here. I thank A.N. Mares for manuscript preparation and S.H. Smith for figure drafting. This work was supported by the U.S. National Science Foundation under grant DPP8716016. This is contribution number 489 of the Geophysical and Polar Research Center, University of WisconsinMadison.

\section{REFERENCES}

Allen, J.R.L. 1985. Principles of physical sedimentology. London, George Allen and Unwin.

Alley, R.B. 1989. Water-pressure coupling of sliding and bed deformation: II. Velocity-depth profiles. J. Glaciol., 35(119), 119-129.

Alley, R.B., D.D. Blankenship, C.R. Bentley, and S.T. Rooney. 1986. Deformation of till beneath Ice Stream B, West Antarctica. Nature, 322(6074), 57-59.

Alley R.B., D.D. Blankenship, S.T. Rooney, and C.R. Bentley. 1987a. Continuous till deformation beneath ice sheets. International Association of Hydrological Sciences Publication 170 (Symposium at Vancouver 1987 - The Physical Basis of Ice Sheet Modelling), 81-91.

Alley, R.B., D.D. Blankenship, C.R. Bentley, and S.T. Rooney. 1987b. Till beneath Ice Stream B. 3. Till deformation: evidence and implications. J. Geophys. Res., 92(B9), 8921-8929.

Alley, R.B., D.D. Blankenship, S.T. Rooney, and C.R. Bentley. 1987c. Till beneath Ice Stream. B. 4. A coupled ice-till flow model. J. Geophys. Res., 92(B9), 8931-8940.

Alley, R.B., D.D. Blankenship, S.T, Rooney, and C.R. Bentley. 1989a. Sedimentation beneath ice shelves - the view from Ice Stream B. Mar. Geol., 85(2/4), 101-120.

Alley, R.B., D.D. Blankenship, S.T. Rooney, and C.R Bentley. 1989b. Water-pressure coupling of sliding and bed deformation: III. Application to Ice Stream B, Antarctica. J. Glaciol., 35(119), 130-139.

Bentley, C.R., and 6 others. 1987. Remote sensing of the Ross ice streams and adjacent Ross Ice Shelf, Antarctica. Ann. Glaciol., 9, 20-29.

Bindschadler, R.A. 1983. The importance of pressurized subglacial water in separation and sliding at the glacier bed. J. Glaciol., 29(101), 3-19.

Blankenship, D.D. and C.R. Bentley, 1986. Seismic mapping of a till at the base of Ice Stream B. [Abstract.] Eidg. Tech. Hochschule, Zürich. Versuchsanst. Wasserbau, Hydrol. Glaziol. Mitt., 90, 29-30.

Blankenship, D.D., C.R. Bentley, S.T. Rooney, and R.B. Alley. 1986. Seismic measurements reveal a saturated porous layer beneath an active Antarctic ice stream. Nature, 322(6074), 54-57.

Blankenship, D.D., C.R. Bentley, S.T. Rooney, and R.B. Alley, 1987. Till beneath Ice Stream B. 1. Properties derived from seismic travel times. $J$. Geophys. Res., 92(B9), 8903-8911.

Blankenship, D.D., S.T. Rooney, R.B. Alley, and C.R. Bentley. 1989. Seismic evidence for a thin basal layer at a second location on Ice Stream B, Antarctica. (Abstract.) Ann. Glaciol., 12, 200.

Bloom, A.L. 1978. Geomorphology. Engelwood Cliffs, NJ, Prentice-Hall.

Boulton, G.S. 1976. The origin of glacially fluted surfaces - observations and theory. J. Glaciol., 17(76), 287-309.

Boulton, G.S. 1979. Processes of glacier erosion on different substrata. J. Glaciol., 23(89), 15-38.

Boulton, G.S, and R.C.A. Hindmarsh. 1987. Sediment 
deformation beneath glaciers: theology and geological consequences. J. Geophys. Res., 92(B9), 9059-9082.

Boulton, G.S. and A.S. Jones. 1979. Stability of temperate ice caps and ice sheets resting on beds of deformable sediment. J. Glaciol., 24(90), 29-43.

Boulton, G.S. and M.A. Paul. 1976. The influence of genetic processes on some geotechnical properties of glacial tills. Q. J. Eng. Geol., 9, 159-194.

Boulton, G.S., D.L. Dent, and E.M. Morris. 1974. Subglacial shearing and crushing, and the role of water pressures in tills from south-east Iceland. Geogr. Ann., 56A(3-4), 135-145.

Brown, N.E., B. Hallet, and D.B. Booth. 1987. Rapid soft bed sliding of the Puget glacial lobe. J. Geophys. Res., 92(B9), 8985-8997.

Clarke, G.K.C. 1987. Subglacial till: a physical framework for its properties and processes. J. Geophys. Res., 92(B9), 9023-9036.

Clarke, G.K.C., S.G. Collins, and D.E. Thompson. 1984. Flow, thermal structure, and subglacial conditions of a surge-type glacier. Can. J. Earth Sci., 21(2), 232-240.

Echelmeyer, $K$. and W. Harrison. 1986. Motion of Jakobshavns Glacier and its relation to surface meltwater: preliminary study. [Abstract.] Eidg. Tech. Hochschule, Zürich. Versuchsanst. Wasserbau, Hydrol. Glaziol. Mitt., 90, 39-40.

Emmett, W.W. 1978. Overland flow. In Kirkby, M.J., ed. Hillslope hydrology. New York, John Wiley and Sons, $145-176$

Engelhardt, H.F., W.D. Harrison, and B. Kamb. 1978. Basal sliding and conditions at the glacier bed as revealed by bore-hole photography. J. Glaciol., 20(84), 469-508.

Fahnestock, M. and N. Humphrey. 1988. Borehole water level measurements, Columbia Glacier, AK. [Abstract.] Ice, 86, 25-26.

Fowler, A.C. 1987. A theory of glacier surges. J. Geophys. Res., 92(B9), 9111-9120.

Freeze, R.A. and J.A. Cherry. 1979. Groundwater. Engelwood Cliffs, NJ, Prentice-Hall.

Goodman, R.E., D.G. Moye, A. van Schalkwyk, and I. Javandel. 1965. Ground water inflows during tunnel driving. Eng. Geol., 2, 39-56.

Haeberli, W. 1986. Factors influencing the distribution of rocky and sedimentary glacier beds. [Abstract.] Eidg. Tech. Hochschule, Zürich. Versuchsanst. Wasserbau, Hydrol. Glaziol. Mitt., 90, 48-49.

Harrison, W., B. Kamb, and H. Engelhardt. 1986. Morphology and motion at the bed of a surge-type glacier. [Abstract.] Eidg. Tech. Hochschule, Zürich. Versuchsanst. Wasserbau, Hydrol. Glaziol. Mitt., 90, 55-56.

Hodge, S.M. 1979. Direct measurement of basal water pressures: progress and problems. J. Glaciol., 23(89), 309-319.

Humphrey, N.F. 1987. Coupling between water pressure and basal sliding in a linked-cavity hydraulic system. International Association of Hydrological Sciences Publication 170 (Symposium at Vancouver 1987 - The Physical Basis of Ice Sheet Modelling), 105-119.

Humphrey, N., C. Raymond, and W. Harrison. 1986 Discharges of turbid water during mini-surges of Variegated Glacier, Alaska, U.S.A. J. Glaciol., 32(111), 195-207.

Iken, A. 1981. The effect of the subglacial water pressure on the sliding velocity of a glacier in an idealized numerical model. J. Glaciol., 27(97), 407-421.

Iverson, R.M. 1985. A constitutive equation for mass-movement behavior. J. Geol., 93(2), 143-160.

Kamb, B. 1970. Sliding motion of glaciers: theory and observation. Rev. Geophys. Space Phys., 8(4), 673-728.

Kamb, B. 1987. Glacier surge mechanism based on linked cavity configuration of the basal water conduit system. $J$. Geophys. Res., 92(B9), 9083-9100.

Lingle, C.S. and T.J. Brown. 1987. A subglacial aquifer bed model and water pressure dependent basal sliding relationship for a West Antaretic ice stream. In Van der Veen, C.J. and J. Oerlemans, eds. Dynamics of the West Antarctic ice sheet. Proceedings of a Workshop held in Utrecht, May 6-8, 1985. Dordrecht, etc., D. Reidel Publishing Company, 249-285.

Lliboutry, L. 1987a. Realistic, yet simple bottom boundary conditions for glaciers and ice sheets. J. Geophys. Res., 92(B9), 9101-9109.
Lliboutry, L. 1987b. Sliding of cold ice sheets. International Association of Hydrological Sciences Publication 170 (Symposium at Vancouver 1987 - The Physical Basis of Ice Sheet Modelling), 131-143.

MacClintock, P. and A. Dreimanis. 1964. Reorientation of till fabric by overriding glacier in the St. Lawrence Valley. Am. J. Sci., 262(1), 133-142.

Meier, M.F. 1989. Relationship between water input, basal water pressure, and sliding of Columbia Glacier, Alaska, U.S.A. (Abstract.) Ann. Glaciol., 12, 214-215.

Nye, J.F. 1953. The flow law of ice from measurements in glacier tunnels, laboratory experiments and the Jungfraufirn borehole experiment. Proc. $R$. Soc. London, Ser. A, 219(1139), 477-489.

Nye, J.F. 1969. A calculation on the sliding of ice over a wavy surface using a Newtonian viscous approximation. Proc. R. Soc. London, Ser. A, 311, 445-467.

Nye, J.F. 1973. Water at the bed of a glacier. International Association of Scientific Hydrology Publication 95 (Symposium at Cambridge 1969 - Hydrology of Glaciers), $189-194$.

Nye, J.F. and F.C. Frank. 1973. Hydrology of the intergranular veins in a temperate glacier. International Association of Scientific Hydrology Publication 95 (Symposium at Cambridge 1969 - Hydrology of Glaciers), 157-161.

Paterson, W.S.B. 1981. The physics of glaciers. Second edition. Oxford, etc., Pergamon Press.

Rooney, S.T., D.D. Blankenship, and C.R Bentley. 1987a. Seismic refraction measurements of crustal structure in West Antarctica. In McKenzie, G.D., ed. Gondwana Six: Structure, Tectonics, and Geophysics. Washington, DC, American Geophysical Union, 1-7. (Geophys. Monogr. 40.)

Rooney, S.T., D.D. Blankenship, R.B. Alley, and C.R. Bentley. 1987b. Till beneath Ice Stream B. 2. Structure and continuity. J. Geophys. Res., 92(B9), 8913-8920.

Rooney, S.T., D.D. Blankenship, R.B. Alley, and C.R. Bentley. 1988. Seismic-reflection profiling of a widespread till beneath Ice Stream B, West Antarctica. (Abstract.) Ann. Glaciol., 11, 210.

Röthlisberger, H. 1972. Water pressure in intra- and subglacial channels. J. Glaciol., 11(62), 177-203.

Shabtaie, S. and C.R. Bentley. 1987. West Antarctic ice streams draining into the Ross Ice Shelf: configuration and mass balance. J. Geophys. Res., 92(B2), 1311-1336.

Shoemaker, E.M. 1986. Subglacial hydrology for an ice sheet resting on a deformable aquifer, J. Glaciol., 32(110), $20-30$.

Sladen, J.A. and W. Wrigley. 1983. Geotechnical properties of lodgement till - a review. In Eyles, N., ed. Glacial geology: an introduction for engineers and earth scientists. Oxford, etc., Pergamon Press, 184-212.

Walder, J.S. 1982. Stability of sheet flow of water beneath temperate glaciers and implications for glacier surging. $J$. Glaciol., 28(99), 273-293.

Walder, J.S. 1986. Hydraulics of subglacial cavities. $J$. Glaciol., 32(112), 439-445.

Walder, J. and B. Hallet. 1979. Geometry of former subglacial water channels and cavities. J. Glaciol., 23(89), 335-346.

Weertman, J. 1957. On the sliding of glaciers. J. Glaciol., $3(21), 33-38$.

Weertman, J. 1964. The theory of glacier sliding. J. Glaciol. $5(39), 287-303$.

Weertman, J. 1969. Water lubrication mechanism of glacier surges. Can. J. Earth Sci., 6(4, Pt. 2), 929-939.

Weertman, J. 1972. General theory of water flow at the base of a glacier or ice sheet. Rev. Geophys. Space Phys., 10(1), 287-333.

Weertman, J. and G.E. Birchfield. 1982. Subglacial water flow under ice streams and West Antarctic ice-sheet stability. Ann. Glaciol., 3, 316-320.

Weertman, J. and G.E. Birchfield. 1983. Stability of sheet water flow under a glacier. J. Glaciol., 29(103), 374-382.

\section{APPENDIX}

Equation (22) relating effective pressure, $N$, shear stress, $\tau_{b}$, and fraction of the bed occupied by a water 
film, $f$, through a constant, $\beta$, was derived assuming all bumps on the glacier bed are the same size. However, if $B$ is independent of bump size, small bumps do not occur on large bumps, and the effect of a bump is independent of its neighbors (the usual assumptions in Weertman sliding theory, e.g. Weertman, 1964, 1969) then Equation (22) is true for a bed with a range of bump sizes. Consider a bed with bumps divided into different size classes, with all bumps in a single class having the same size. Bumps of the $j$ th size class support pressure $P_{\mathrm{b} j}$ on fractional area $s_{j}$, where $\Sigma s_{j}=s$, with the summation taken over the $j$ size classes. Then we can rewrite Equation (18) as

$$
\Sigma\left(P_{\mathrm{b} j} s_{j}\right)+P_{\mathrm{w}}\left(1-\Sigma s_{j}\right)=P_{\mathrm{i}}
$$

whence

$$
\Sigma\left(P_{\mathrm{b} j} s_{j}\right)-P_{\mathrm{w}} \Sigma s_{j}=P_{\mathrm{i}}-P_{\mathrm{w}} .
$$

The total shear force on some arbitrary area of the bed, $A$, is $\tau_{b} A$. Define the quantities $\tau_{j}$ such that the shear force supported by the $j$ th size class on area $s_{j} A$ is $\tau_{j} A$, where $\Sigma\left(\tau_{j} A\right)=\tau_{\mathrm{b}} A$ (and thus $\left.\Sigma \tau_{j}=\tau_{\mathrm{b}}\right)$. The shear stress on a clast in the $j$ th class then is $\tau_{j} A /\left(s_{j} A\right)=\tau_{j} / s_{j}$. For the $j$ th size class, Equation (20) becomes

$$
P_{\mathrm{b} j}=P_{\mathrm{i}}+\frac{B \tau_{j}}{s_{j}} .
$$

Substituting for $P_{\mathrm{b} j}$ in Equation (A2) from Equation (A3) yields

$$
\Sigma\left(P_{\mathrm{i}} s_{j}+B \tau_{j}\right)-P_{\mathrm{w}} \Sigma s_{j}=P_{\mathrm{i}}-P_{\mathrm{w}}
$$

or, noting that $P_{i}$ and $\beta$ are independent of $j, \Sigma s_{j}=s$, and $\Sigma \tau_{j}=\boldsymbol{\tau}$,

$$
P_{\mathrm{i}^{s}}+B \tau_{\mathrm{b}}-P_{\mathrm{w}^{s}}=P_{\mathrm{i}}-P_{\mathrm{w}}
$$

Algebraic manipulation then regains Equation (21) and hence Equation (22).

$M S$, received I August 1988 and in revised form 15 October 1988 